\title{
Selvmord
}

\section{og medier: Tiltak gir støtte}

Ved Valérie Lesage

Huordan kan det ha seg at en journalist i en canadisk dagsavis

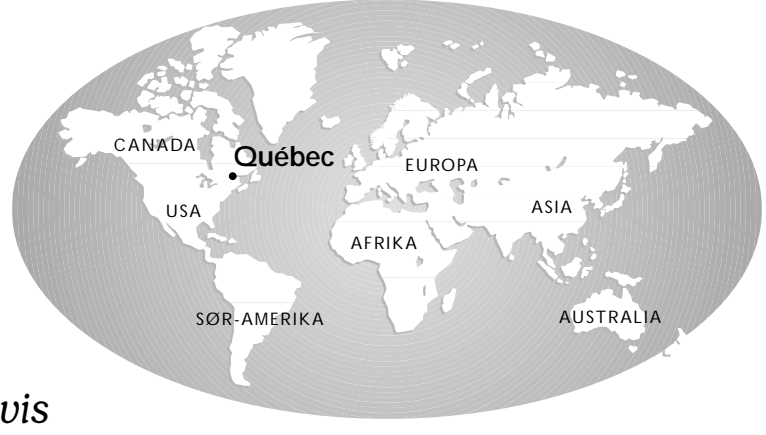

blir sendt til Norge og Finland for å skrive flere reportasjer om selumordsforebyggende strategier $i$ de to landene? Valérie Lesage forteller her om bakgrunnen for reportasjene og reaksjoner fra leserne, og om "Forebyggende tiltak mot selumord"-uken i canadisk fjernsyn.

For to år siden tok hjernehinnebetennelse livet av rundt ti barn i Q uébecregionen. Temaet fylte side opp og side ned $\mathrm{i}$ avisene i flere uker og ble dekket av timevis med sendetid i TV-kanaler og radiostasjoner. Selvmord tar gjennomsnittlig livet av 1400 personer per år i Q uébec-provinsen. Selvsagt blir det fra tid til annen snakket om, men fenomenet oppnår aldri like mye oppmerksomhet som hjernehinnebetennel se. Det er fortsatt et tabuemne, man vet ikke riktig om man skal snakke om det, og hvisja, på hvilken måte. Blant folk flest er det mange som tenker at det dreier seg om den enkeltes frihet til å velge. De mener at man ikke skal blande seg inn i folks "private saker". Sett fra denne synsvinkelen er det lett å tenke seg at det å skrive om hvordan man forebygger selvmord, ikke er særlig "sal gbart" for en avis. D erfor var jeg høyst overrasket over at min avis, Le Soleil, lot seg overtale til å sende meg til N orge og Finland for å skrive om forebyggende strategier i de to landene. Ikke bare var mine sjefer parate til å investere tusenvis av dollar i prosjektet, men også til å ofre mye spalteplass. Totalt et titalls artikler, hvorav én på lederplass. Det var ingen sensasjoner knyttet til denne avgjørelsen: Prosjektet skulle ikke være å rapportere dramatiske hendel ser, men snarere å sette myndigheten es tiltak for å redusere antall selvmord i perspektiv - å studere hvilke modeller som kunne tenkes å bevege Q uébec til forebyggende tiltak.

Til dags dato hadde temaet aldri vært behandlet på denne måten i våre medier. Kanskje var det nettopp det som var avgjørende for sjefredaktøren. Bare for et år siden var det mye vanskeligere å overbevise en av sjefene i TV-kanalen Radio$C$ anada om hvor relevant en slik ti minutters reportasje ville være når den årlige "Forebyggende tiltak mot selvmord"-uken fant sted. Talsmannen for denne begivenheten var en dommer. $\mathrm{H}$ an s sønn hadde gjort selvmord i 1995, 25 år gammel. Denne mannen hadde bedt meg om å hjelpe seg med å spre informasjon, noe jeg straks ville være med på. Dommer Sheenan hadde mye å lære fra seg om hvordan selvmordstanker utvikler seg, om hvordan man kan hjelpe den som lider, og om sorgen hos de etterlatte. $\mathrm{H}$ an holdt foredrag på skolene for å informere ungdom - for å beskytte liv. Sjefen for Radio-C anada ga sin tillatelse til reportasjen om selvmord på betingelse av et eksklusivt intervju med dommeren. Det var helt meningsløst, for hans informasjon om forebygging skulle jo høres av flest mulig. Det kunne ikke kokes ned til et spørsmål om seertall i en så alvorlig sak. Sjefen endte til slutt med å forstå det, men han forlangte å få være først ... Det var ekstremt pinlig å måtte forklare slike hensyn til en mann som hadde vært gjennom så store prøvelser som dommer Sheenan. I midlertid ble det aldri så galt at det ikke var godt for noe, for reportasjen vi gjorde med ham var så dypt gripende at den åpnet andre dører. Programledere som tidligere hadde avslått å berøre temaet sammen med dommeren, ombestemte seg. Resultatet var at aldri hadde Forebyggende tiltak mot selvmord-uken hatt så stor suksess.

Jeg vil også tilføye at vi mottok en rekke tel efoner og brev fra seerne. $\mathrm{N}$ oen trengte hjelp, andre ville tilby sin hjelp, alle var fortvilet over hvor omfattende problemet er og over mangelen på en handlingsplan fra myndighetenes side. Både reportasjen med dommer Sheenan og artiklene som ble skrevet etter reisen til N orge og Finland, inneholdt forslag til strategier. De går ut på å se hva som kan gjøres fra det offentliges side, men også hva hver enkelt av oss kan gjøre for å bekjempe selvmord. Reaksjonene fra publikum har vært svært positive, fordi folk har forstått at hver enkelt kan gjøre noe. Ingen skal tro at de er maktesløse.

A rtiklene om $\mathrm{N}$ orge og Finland sto i avisen i slutten av september 2002, og to måneder senere mottok avisen fortsatt brev om temaet. Til og med psykiatere og ledere for selvmordssentre har skrevet til oss for å få mer informasjon eller for å gratulere oss. En mor som hadde mistet sønnen uken før artiklene sto i avisen, ringte for å takke og for å fortelle at de hadde vært til stor trøst for henne og familien.

A rtiklene om N orge og Finland har også satt temaet på politikernes dagsorden. For første gan er lederne for de tre største politiske partiene i provinsen blitt spurt om sine visjoner når det gjelder forebyggende tiltak. Før jul bestemte opposisjonslederen seg for å invitere alle parlamentsmedlemmer til å samarbeide om å bygge opp en forebyggingsstrategi. Etter lenge å ha vært overlatt til en folkevalgt minister ser det nå ut til at forebygging av selvmord klatrer litt oppover prioriteringsstigen

Vi skal følge nøye med på utviklingen i saken, men alt dette viser at det å snakke om selvmord i mediene kan føre til noe mye mer positivt enn taushet.

Valérie Lesage er journalist i avisen Le Soleil, Q uébec, $C$ anada.

(A rtikkelen er oversatt av A ne T hurid B rudi.)

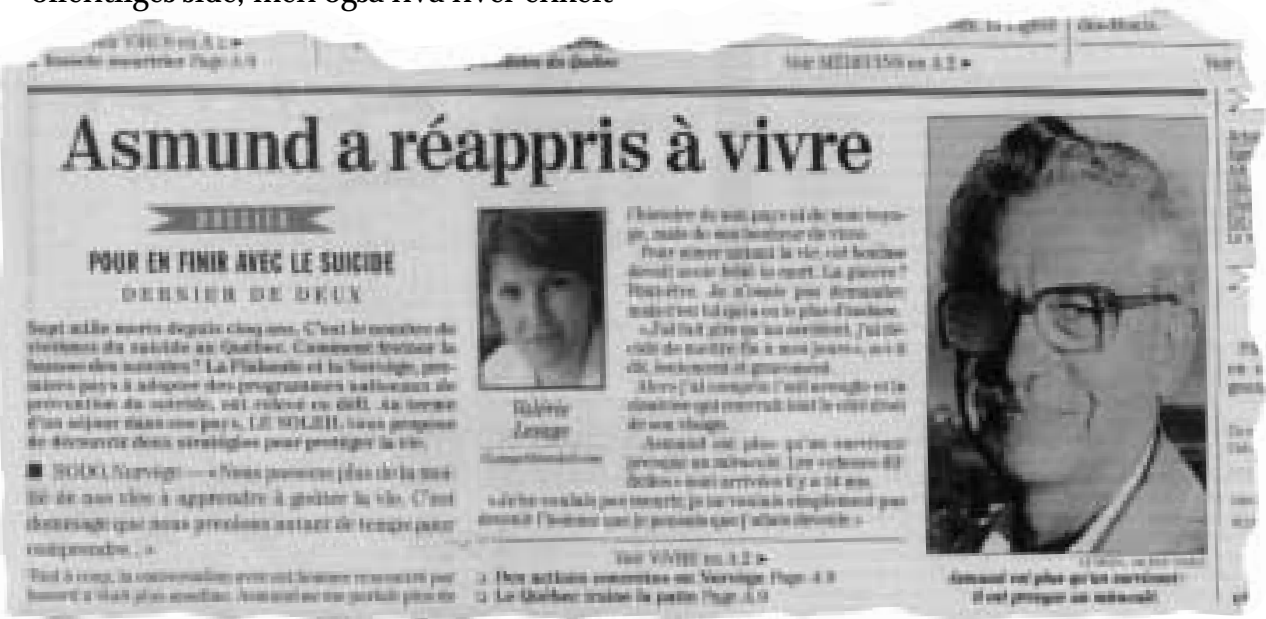

Faksimile fra Le Soleil 22.09.02 